\title{
PERLINDUNGAN HUKUM FRANCHISEE ATAS KEPAILITAN FRANCHISOR
}

\author{
Prehantoro \\ Fakultas Hukum Universitas Yos Sudarso Surabaya \\ e-mail:pre_hantoro@yahoo.com
}

\begin{abstract}
ABSTRAK
Sita umum atas harta kekayaan debitor selaku franchisor karena kepailitan tidak membatalkan perjanjian franchise ketika dalam perjanjian tersebut dimuat klausula keberlanjutan perjanjian franchise. Apabila klausula tersebut tidak dicantumkan, maka perlindungan hukum franchisee didapatkan melalui pengajuan permohonan untuk melanjutkan perjanjian franchise kepada kurator dari franchisor, atau dengan meminta ganti kerugian sebagai kreditor konkuren.
\end{abstract}

Kata Kunci: Perjanjian Franchise, franchisee, franchisor.

\section{ABSTRACT}

Common seizure of debtors wealth, as a Franchisor that caused of bankrupt will not have an implication of Franchise contract cancellation, if in the related contract has a clause that the Franchise contract will be continued even if debtors is bankrupt. If that clause was not written in the related Franchise contract, then the Franchisee law protection shall born through application to the curator from Franchisor, to continue the Franchisee contract. Otherwise the Franchisee might ask for compensation as a concurrent creditor.

Keywords: Franchise Agreement, franchisee, franchisor.

\section{PENDAHULUAN}

Pelaku usaha baru memiliki beberapa persoalan, sebab nantinya pelaku usaha akan menghadapi tantangan dan persaingan pasar. Dalam memulai suatu bisnis, persaingan usaha bukan merupakan hal yang baru. Bagus atau tidaknya suatu usaha akan ditentukan dengan permintaan pasar. ${ }^{1}$

Pelaku usaha yang baru membutuhkan usaha yang lebih besar apabila dibandingkan dengan pelaku usaha lama untuk menarik konsumen, sebab pelaku usaha lama biasanya memiliki konsumen yang telah menjadi pelanggan. Produk dari pelaku usaha baru harus memiliki kelebihan dibandingkan dengan pelaku usaha yang lama.

Franchise atau waralaba ${ }^{2}$ dapat dikatakan merupakan suatu sistem pemasaran yang

\footnotetext{
${ }^{1}$ CSBisnisUKM, Bagaimana Cara Menghadapi Persaingan Pasar?, http://bisnisukam.com/Bagaimana-Cara-MenghadapiPersaingan-Pasar.html, diakses pada tanggal 4 Oktober 2014.

${ }^{2}$ Pasal 1 angka 1 PP No. 42 Tahun 2007 menyatakan bahwa waralaba adalah hak khusus yang dimiliki orang perseorangan atau badan usaha terhadap sistem bisnis dengan ciri khas usaha dalam rangka memasarkan barang dan/atau jasa yang telah terbukti berhasil dan dapat dimanfaatkan dan/atau digunakan pihak lain berdasarkan perjanjian waralaba.
}

menguntungkan bagi pelaku usaha. Franchise atau waralaba dapat dikatakan memiliki peran untuk melakukan komunikasi pemasaran, yaitu dengan melakukan kemitraan antara pelaku usaha yang baru dan pelaku usaha lama. Pelaku usaha lama menggunakan sistem ini untuk memperluas jaringannya, sedangkan pelaku usaha baru mendapatkan konsumennya tanpa perlu melakukan usaha yang tinggi untuk mengenalkan produknya, di mana di dalam beberapa produk yang menggunakan sistem ini, seperti KFC, Mc'd, Breadtalk, serta Teh Poci, konsumennya cukup banyak, bahkan konsumen rela mengantri cukup lama untuk mendapatkan produk tersebut.

Data yang ada pada tahun 2014 menyatakan bahwa franchise lokal pada saat ini ada 12.000 bisnis dengan jumlah gerai mencapai 23.000. Pada tahun 2015 ditargetkan mengalami peningkatan sebesar $15-20 \%{ }^{3}$

${ }^{3}$ Administrator, Bisnis Waralaba Diproyeksikan naik 15 20\% Tahun ini, http://bisniskeuangankompas.co/read/ diakses pada tanggal 10 September 2014. 
Perjanjian franchisee 4 merupakan kesepakatan tertulis berupa pemberian lisensi dari franchisor kepada pihak franchisee berupa hak kekayaan intelektual, seperti hak cipta, merek, paten, serta rahasia dagang. Sedangkan timbal balik yang diberikan oleh franchisee adalah berupa pembayaran fee.

Permasalahan yang dapat timbul akibat perjanjian franchise tersebut, baik adanya pemutusan secara sepihak oleh franchisor, atau pun apabila franchisor dipailitkan. Kepailitan merupakan suatu sita umum atas semua kekayaan debitor pailit yang pengurusan dan pemberesannya dilakukan oleh kurator di bawah pengawasan hakim pengawas sebagaimana di atur di dalam undang-undang ini. ${ }^{5}$

Putusan pailit adalah serta merta dan dapat dijalankan terlebih dahulu meskipun masih dilakukan upaya hukum terhadap putusan tersebut. Sehingga ratio legisnya adalah bahwa kepailitan pada dasarnya merupakan alat untuk mempercepat likuidasi terhadap harta-harta debitor untuk digunakan sebagai pembayaran utang-utangnya. Kepailitan juga merupakan sarana untuk menghindari perebutan harta kekayaan debitor pailit dari eksekusi yang tidak legal dari para kreditor serta perlombaan untuk mendapatkan harta debitor. ${ }^{6}$

Harta debitor dalam hal ini merupakan segala kebendaan si berutang, baik yang bergerak maupun yang tidak bergerak, baik yang sudah ada maupun yang belum ada, nantinya pendapatan atas barangbarang tersebut akan dibagi menurut keseimbangan, kecuali ada alasan-alasan dari kreditor untuk didahulukan. ${ }^{7}$

Hak atas Intelektual sendiri dapat dikatakan merupakan suatu hak milik perorangan yang tidak berwujud, dengan demikian hak atas kekayaan intelektual dapat dikatakan termasuk merupakan harta yang terdapat pada Pasal 1131 BW dan Pasal 1132

\footnotetext{
${ }^{4}$ Pasal 5 Peraturan Menteri Perdagangan Republik Indonesia Nomor 53/M-DAG/PER/8/2012 tentang Penyelenggaraan Waralaba menyatakan bahwa penyelenggaraan waralaba harus didasarkan pada perjanjian waralaba yang mempunyai kedudukan hukum setara dan terhadap mereka berlaku hukum Indonesia.

${ }^{5}$ Pasal 1.1 UU No. 37 Tahun 2004 tentang Kepailitan dan dan Penundaan Kewajiban Pembayaran.

${ }^{6}$ Hadi Shubhan, Hukum Kepailitan, Prinsip, Norma dan Praktik di Peradilan, Kencana Prenadamedia Group, Jakarta, h. 163.

${ }^{7}$ Pasal 1131BW-Pasal 1132 BW.
}

BW, sehingga hak atas kekayaan intelektual masuk ke dalam sitaan umum dan termasuk harta pailit.

Berdasarkan latar belakang yang telah diuraikan di atas, maka yang menjadi permasalahan dalam penulisan ini, karakteristik dari perjanjian franchise dan perlindungan hukum terhadap franchisee tehadap putusan pailit franchisor.

\section{METODE}

Penelitian dalam penulisan ini menggunakan metode normatif dengan menganalisa peraturan perundang-undangan, antara lain yang dikaji: PP No. 42 Tahun 2007 tentang Waralaba, dan Burgerlijk Wetbook.

\section{PEMBAHASAN}

\section{Karakteristik Hukum Perjanjian Franchise}

Pasal 4 PP No. 42 Tahun 2007 dipersyaratkan setiap kontrak waralaba bentuknya wajib untuk dibuat secara tertulis oleh para pihak. Eksistensi dari kontrak waralaba sejatinya adalah kontrak innominaat. ${ }^{8}$ Sekalipun tunduk pada asas kebebasan berkontrak, kerangka dari sutau kontrak waralaba telah ditentukan secara imperatif dalam Pasal 5 PP No. 42 Tahun 2007.

Perjanjian franchise yang tujuannya dibuat terhadap sutau wilayah atau segi area geografis untuk periode waktu tertentu disebut teritorial franchise. Dua bentuk waralaba teritorial adalah perjanjian pengembang franchise dan master perjanjian franchise. Dalam sebuah waralaba internasional dimana master lokal franchisor mengontrol langsung hubungan bisnis dengan franchisee. Franchisor harus secara aktif turut serta dalam joint venture tersebut untuk menjalankan waralaba. Format dari sebuah joint venture kadang menyediakan keamanan bagi pemilik hak kekayaan intelektual, karena dengan franchisor terlibat dalam management join venture tersebut, penggunaan sistem waralaba oleh franchisee dapat terkontrol. ${ }^{9}$ Franchisor tidak mencampuri urusan manajemen dan pemasaran pihak franchisee.

\footnotetext{
${ }^{8}$ Kontrak innominaat merupakan kontak-kontrak yang timbul dan berkembang di dalam praktik. Timbulnya kontrak tersebut karena adanya asas kebebasan berkontrak sebagaimana yang tercantum dalam Pasal 1338 ayat (1) BW, Salim H.S., Perkembangan Hukum Kontrak Innominaat di Indonesia, Sinar Grafika, Jakarta, 2010, h. 1.

9 Suyud Margono, Aspek Hukum Komersialisasi Aset Intelektual, Nuansa Aulia, Bandung, 2010, h. 57.
} 
Misalnya KFC di Amerika yang memberikan hak perusahaan KFC di Indonesia. ${ }^{10}$

Hubungan hukum antara franchisor dan franchisee timbul diakibatkan karena perjanjian franchise. Oleh karena itu dapat dikatakan bahwa di antara keduanya timbul suatu hak dan kewajiban, sebagaimana yang tercantum dalam Pasal $1338 \mathrm{BW}^{11}$ yang dikenal juga sebagai asas privity of contract, di mana perjanjian mengikat seperti undang-undang bagi para pihak, demikian pula perjanjian franchise bagi franchisor dan franchisee.

Pasal 1338 BW menyatakan bahwa perjanjian harus memenuhi suatu syarat tertentu agar dapat mengikat seperti para pihak bagi para pihak, yaitu dengan memenuhi suatu persyaratan yang terdapat pada Pasal 1320 BW.

Syarat-syarat subjektif yang dimaksud adalah syarat-syarat yang tertuang dalam ayat (1) dan (2) Pasal 1320 BW, yaitu kesepakatan dan kecakapan. Seseorang dikatakan cakap apabila telah berumur 18 Tahun, sebagaimana terdapat pada UU No. 1 Tahun 1974 tentang Perkawinan atau telah menikah sehingga dapat dikatakan seseorang melakukan pekerjaan. Akan tetapi Pasal 1321 BW menyatakan bahwa sepakat dianggap tidak dilakukan apabila telah terjadi kekhilafan, paksaan atau penipuan. Franchisor dan franchisee melakukan kesepakatan harus dilakukan dengan tanpa adanya paksaan, penipuan, atau khilaf karena obyek.

Sebelum para pihak terikat dalam suatu perjanjian franchise, pemberi franchise wajib menyampaikan keterangan tertulis kepada penerima franchise mengenai kegiatan usahanya termasuk neraca dan daftar rugi laba selama 2 (dua) tahun terakhir, hak atas kekayaan intelektual atau penemuan atau ciri khas usaha yang menjadi obyek franchise. Pemberi franchise juga harus merinci fasilitas-fasilitas atau bantuan-bantuan yang akan ditawarkan kepada penerima franchise, hak dan kewajiban bagi masingmasing pihak, cara-cara pengakhiran, pembatan dan perpanjangan perjanjian tersebut, serta hal-hal lain

\footnotetext{
${ }^{10}$ Sonny Sumarsono, Manajemen Bisnis Waralaba, Graha Ilmu, Yogyakarta, 2009, h. 88

${ }^{11}$ Pasal 1338 BW menyatakan bahwa semua perjanjian yang dibuat secara sah beraku sebagai undang-undang bagi mereka yang membuatnya. Suatu perjanjian tidak dapat ditarik kembali selain dengan sepakat kedua belah pihak, atau karena alasanalasan yang oleh undang-undang dinyatakan untuk itu. Semua perjanjian harus dilaksanakan dengan itikad baik.
}

yang perlu diketahui oleh penerima franchise dalam rangka pelaksanaan perjanjian franchise.

Syarat subjektif, apabila tidak dipenuhi dalam suatu perjanjian, maka perjanjian tersebut dapat dibatalkan, dan hak dan kewajiban yang telah dilakukan oleh para pihak harus dikembalikan seperti semula.

Syarat yang kedua adalah syarat obyektif. Pasal 1320 BW ayat (3) dan (4) terdapat dua macam, yaitu suatu obyek tertentu dan suatu kausa yang diperbolehkan. Suatu obyek tertentu adalah jelasnya obyek yang diatur oleh perjanjian setidak-tidaknya ditentukan. Hal ini penting untuk memberikan jaminan atau kepastian kepada para pihak dan mencegah timbulnya kontrak fiktif.

Perjanjian franchise, berdasarkan obyek perjanjiannya adalah Hak atas Kekayaan Intelektual membedakan franchise atas: franchise produk; dan franchise format bisnis. Menurut Stephen Fox, bisnis franchise produk diidentifikasikan dengan produk atau nama dagang franchisor. Dalam franchise jenis ini franchisor adalah pembuat produk. Sedangkan pada franchise format bisnis adalah penjualan barang dan jasa berdasarkan sistem penjualan dari franchisor.

Syarat objektif yang kedua adalah suatu sebab yang diperbolehkan, maksudnya isi perjanjian tidak boleh bertentangan dengan perundang-undangan yang sifatnya memaksa, ketertiban umum, atau kesusilaan.

Apabila syarat obyektif ini dilanggar, maka akan berakibat batal demi hukum, sehingga tidak ada peristiwa hukum yang menimbulkan akibat hukum serta tidak ada hak dan kewajiban yang timbul di antara kedua belah pihak sehingga hukum tidak dapat melakukan perlindungan kepada kedua belah pihak.

Perjanjian yang memenuhi syarat sahnya perjanjian sebagaimana dijelaskan di atas, maka akan berlaku mengikat bagi kedua belah pihak, hal tersebut memiliki arti bahwa telah terjadi suatu peristiwa hukum yang menimbulkan suatu hubungan hukum antara franchise dan franchisor, di mana hal tersebut memiliki arti bahwa timbul suatu akibat hukum.

Akibat hukum memiliki arti suatu akibat yang akan menimbulkan suatu hak dan kewajiban bagi franchise dan franchisor.

Tiga bentuk perjanjian franchise tertulis, yaitu; pertama, Perjanjian di bawah tangan ditandatangani oleh para pihak yang bersangkutan saja; kedua, Perjanjian dengan saksi notaris untuk melegalisir tanda tangan para pihak; ketiga, Perjanjian yang 
dibuat dihadapan dan oleh notaris dalam bentuk akta notaril ${ }^{12}$, sesuai Pasal 4 (1) PP No. 42 Tahun 2007. Akan tetapi apabila dalam prakteknya, sarana komunikasi dan instruksi yang dipergunakan berbahasa asing, maka harus diterjemahkan ke dalam bahasa Indonesia, sehingga harus ada klausula bahwa bahasa Indonesia adalah bahasa resmi dari perjanjian franchise tersebut.

Isi perjanjian franchise memuat klausula paling sedikit: nama dan alamat para pihak; Jenis Hak Kekayaan Intelektual; kegiatan usaha; hak dan kewajiban para pihak; bantuan, fasilitas, bimbingan operasional, pelatihan dan pemasaran yang diberikan pemberi franchise kepada penerima franchise; wilayah usaha; jangka waktu perjanjian; tata cara pembayaran imbalan; kepemilikan; penyelesaian sengketa; dan tata cara perpanjangan, pengakhiran dan pemutusan perjanjian. Meskipun demikian para pihak diperbolehkan untuk membuat pengaturan secara khusus. ${ }^{13}$

Sepuluh hal yang harus diperhatikan di dalam pembuatan kontrak dibuat secara terperinci, yang terdiri dari: ${ }^{14}$ pertama, perencanaan dan identifikasi kepentingan pemberi franchise sebagai pemilik, hal ini tentunya akan menyangkut hal-hal seperti merek dagang, hak cipta dan sistem bisnis pemberi franchise beserta know how; kedua, sifat serta luasnya hak-hak yang diberikan kepada penerima franchise, hal ini menyangkut wilayah operasi dan pemberian hak-hak secara formal untuk menggunakan merek dagang, nama dagang dan seterusnya; ketiga, jangka waktu perjanjian, prinsip dasar dalam mengatur hal ini bahwa hubungan franchise harus dapat bertaubat pada jangka waktu yang lama, atau setidak-tidaknya selama waktu 5 tahun dengan klausula kontrak franchise yang dapat diperpanjang; keempat, sifat dan luasnya jasa-jasa yang diberikan, baik pada masa-masa awal maupun selanjutnya. Ini akan menyangkut jasajasa pendahuluan yang memungkinkan franchisee untuk memulai, ditraining, dan dilengkapi dengan peralatan untuk melakukan bisnis. Selanjutnya, pemberi franchise akan memberikan jasa-jasa secara terperinci hendaknya di atur dalam kontrak dan juga

\footnotetext{
${ }^{12}$ Salim HS, Perkembangan Hukum Kontrak di Indonesia, Sinar Grafika, Jakarta, 2005, h. 32.

${ }^{13}$ Pasal 5 PP No. 42 Tahun 2007.

${ }^{14}$ Martin Mendelson, Franchising, Petunjuk Praktis bagi Martin Mendelson, Franchising, Petunjuk Praktis bagi Franchisor dan Franchisee, Pustaka Binaman Pressindo, Jakarta, 1997, h. 58-63.
}

diperkenankan untuk memperkenalkan ide-ide baru; kelima, kewajiban-kewajiban awal dan selanjutnya dari franchisee. Ini akan mengatur kewajiban untuk menerima beban keuangan dalam mendirikan bisnis sesuai dengan persyaratan franchisor serta melaksanakan sesuai dengan persyaratan franchisor serta melaksanakan sesuai dengan sistem operasi, akunting dan administrasi lainnya untuk memastikan bahwa informasi yang penting tersedia untuk kedua belah pihak. Sistem-sistem ini akan dikemukakan dalam petunjuk operasional yang akan disampaikan kepada franchisee selama pelatihan dan akan terus tersedia sebagai pedoman/ referensi setelah ia membuka bisnis; keenam, kontrol operasional terhadap penerima franchise. Kontrolkontrol tersebut untuk memastikan bahwa standar operasional dikontrol secara layak, karena kegagalan untuk mempertahankan standar pada satu unit penerima franchise akan mengganggu keseluruhan jaringan franchise; ketujuh, penjualan bisnis. Salah satu kunci sukses dari franchise adalah motivasi yang ditanamkannya kepada franchisee, disertai sifat kewirausahaan franchisee, serta insentif yang dihasilkan dari capital gain. Untuk alasan ini, bisnis difranchise harus dapat dijual. Seorang franchisor hendaknya sangat selektif ketika mempertimbangkan lamaran dari franchisee; kedelapan, kematian franchisee tidak menyebabkan putusnya perjanjian franchise; kesembilan, dalam kontrak ditentukan mengenai penyelesaian sengketa yang mungkin timbul dengan arbitrase; kesepuluh, harus ada ketentuan yang mengatur mengenai berakhirnya perjanjian.

Pengaturan mengenai hak dan kewajiban dari franchisor dan franchisee dapat diuraikan sebagai berikut: ${ }^{15}$ pertama, franchisor wajib memberikan prospektus penawaran franchisee kepada calon franchisee pada saat penawaran; kedua, franchisor wajib memberikan pembinaan dalam bentuk pelatihan, bimbingan operasional manajemen, pemasaran, penelitian dan pengembangan kepada franchisee secara berkesinambungan; ketiga, franchisor dan franchisee wajib mengutamakan penggunaan barang dan/atau jasa hasil produksi dalam negeri sepanjang memenuhi standar mutu barang dan/atau jasa yang ditetapkan secara tertulis oleh franchisor; keempat, franchisor harus bekerjasama dengan pengusaha kecil dan menengah di daerah setempat sebagai franchisee

\footnotetext{
${ }^{15}$ Pasal 7-11 PP No. 42 Tahun 2007.
} 
atau pemasok barang dan/atau jasa sepanjang memenuhi ketentuan persyaratan yang ditetapkan oleh franchisor; kelima, franchisor wajib mendaftarkan prospektus penawaran franchise sebelum membuat perjanjian franchise dengan franchisee; keenam, franchisee wajib mendaftarkan perjanjian franchise.

Secara umum dapat dirumuskan kewajibankewajiban franchisor: memberikan segala macam informasi yang berhubungan dengan hak atas kekayaan intelektual, penemuan atau ciri khas usaha misalnya sistem manajemen, cara penjualan atau penataan atau cara distribusi yang merupakan karakteristik khusus yang menjadi objek franchise dalam rangka pelaksanaan franchise yang diberikan tersebut; dan memberikan bantuan pada franchisee pembinaan, bimbingan dan pelatihan kepada franchisee.

Sedangkan hak franchisor: 1. melakukan pengawasan jalannya pelaksanaan franchise; 2 . memperoleh laporan-laporan secara berkala atas jalannya kegiatan usaha franchisee; 3. melaksanakan inspeksi pada daerah kerja franchisee guna memastikan bahwa franchise yang diberikan telah dilaksanakan sebagaimana mestinya; 4. sampai batas tertentu mewajibkan franchisee dalam halhal tertentu, untuk membeli barang modal dan atau barang-barang tertentu lainnya dari franchisor; 5 . mewajibkan franchisee untuk menjaga kerahasiaan hak atas kekayaan intelektual, penemuan atau ciri khas usaha; 6. mewajibkan franchisee tidak melakukan kegiatan yang sejenis, serupa, ataupun yang langsung maupun tidak langsung dapat menimbulkan persaingan dengan kegiatan usaha yang mempergunakan hak atas kekayaan intelektual, penemuan, atau ciri khas usaha misalnya sistem manajemen, cara penjualan atau penataan atau cara distribusi yang merupakan karakteristik khusus yang menjadi objek franchise; 7. menerima pembayaran royalty dalam bentuk, jenis, dan jumlah yang dianggap layak olehnya; 8. meminta dilakukannya pendaftaran atas franchise yang dberikan kepada franchisee; 9. atas pengakhiran franchise, meminta kepada franchisee untuk mengembalikan seluruh data, informasi maupun keterangan yang diperoleh penerima franchise selama masa pelaksanaan franchise; 10. atas pengakhiran waralaba melarang franchisee untuk memanfaatkan lebih lanjut seluruh data, informasi, maupun keterangan yang diperoleh oleh franchisee selama masa pelaksanaan franchise; 11. atas pengakhiran franchise, melarang franchisee untuk tetap melaksanakan kegiatan yang sejenis, serupa, ataupun yang secara langsung maupun tidak langsung dapat menimbulkan persaingan dengan mempergunakan hak atas kekayaan intelektual, penemuan atau ciri khas usaha; 12. pemberian franchise, kecuali yang bersifat franchise.

Kewajiban franchisee adalah: 1. melaksanakan seluruh instruksi yang diberikan oleh franchisor kepada guna melaksanakan hak atas kekayaan intelektual, penemuan atau ciri khas usaha; 2. memberi keleluasaan bagi franchisor untuk melakukan pengawasan maupun inspeksi berkala maupun secara tiba-tiba, guna memastikan bahwa franchisee telah melaksanakan franchise yang diberikan dengan baik; 3. memberikan laporan-laporan baik secara berkala maupun atas permintaan khusus dari franchisor; 4. sampai batas tertentu membeli barang modal ataupun barang-barang tertentu lainnya dalam rangka pelaksanaan franchise dari franchisor; 5. menjaga kerahasiaan atas hak atas kekayaan intelektual penemuan atau ciri khas usaha; 6 . melaporkan segala pelanggaran hak atas kekayaan intelektual, penemuan atau ciri khas usaha; 7. tidak memanfaatkan hak atas kekayaan intelektual, penemuan atau ciri khas usaha; 8. melakukan pendaftaran franchise; 9. tidak melakukan kegiatan yang sejenis, serupa, ataupun yang secara langsung maupun tidak langsung dapat menimbulkan persaingan dengan kegiatan usaha yang mempergunakan hak atas kekayaan intelektual, penemuan atau ciri khas usaha; 10. melakukan pembayaran royalty dalam bentuk, jenis, dan jumlah yang telah disepakati bersama; 11. atas pengakhiran franchise, mengembalikan seluruh data, informasi maupun keterangan yang diperolehnya; 12. atas pengakhiran franchise, tidak memanfaatkan lebih lanjut seluruh data, informasi maupun keterangan yang diperoleh oleh franchisee selama masa pelaksanaan franchise; 12. atas pengakhiran franchise, tidak lagi melakukan kegiatan sejenis.

Disamping kewajiban franchisee sebagaimana diatas, sebagai franchisee dalam perjanjian franchise juga ditegaskan beberapa hak sebagai franchisee. Hak franchisee yang dimaksud antara lain adalah: 1. memperoleh segala macam informasi yang berhubungan dengan hak atas kekayaan intelektual, penemuan atau ciri usaha; 2. memperoleh bantuan dari franchisor atas segala macam cara pemanfaatan dan atau penggunaan hak atas kekayaan intelektual penemuan atau ciri khas usaha. 


\section{Akibat Hukum Kepailitan terhadap Harta Kekayaan Debitur Pailit}

Kepailitan mengakibatkan seluruh harta kekayaan debitur serta segala sesuatu yang diperoleh selama kepailitan berada dalam sitaan umum sejak saat putusan pernyataan pailit diucapkan, semenjak pukul 00.00 WIB, kecuali: a. benda, termasuk hewan yang benar-benar dibutuhkan oleh debitur sehubungan dengan, pekerjaannya perlengkapannya, alat-alat medis yang dipergunakan untuk kesehatan, tempat tidur, dan perlengkapannya yang dipergunakan oleh debitur dan keluarganya yang terdapat ditempat itu; $b$. segala sesuatu yang diperoleh debitur dari pekerjaan sendiri sebagai penggajian dari suatu jabatan atau jasa, sebagai upah, pensiun, uang tunjangan, sejauh yang ditentukan oleh Hakim Pengawas; c. atas uang yang diberikan kepada debitur untuk memenuhi suatu kewajiban memberikan nafkah. ${ }^{16}$

\section{Hak Kekayaan Intelektual sebagai Hak Kebendaan}

Barang adalah tiap benda dan tiap hak yang dapat menjadi objek dari hak milik. ${ }^{17}$ Adapun untuk menjadi objek hukum, haruslah memenuhi syaratsyarat tertentu, yaitu penguasaan manusia, memiliki nilai ekonomi dan karenanya dapat dijadikan sebagai objek. Bahkan kebendaan yang mempunyai nilai ekonomis dapat dijadikan suatu perikatan atau utang tertentu dari seorang debiturnya kepada krediturnya. ${ }^{18}$

Benda dibedakan menjadi dua, yaitu benda bergerak dan benda tidak bergerak. ${ }^{19}$ Suatu benda dimasukkan di dalam golongan benda tidak bergerak pertama karena sifatnya, kedua karena tujuan pemakaiannnya, dan ketiga karena tujuan pemakaiannya. Sedangkan benda digolongkan menjadi benda bergerak karena sifatnya atau karena ditentukan oleh undang-undang, karena sifatnya tidak tergabung oleh tanah atau karena undang-undang. ${ }^{20}$

Hak atas barang tidak berwujud adalah hak atas suatu produk gagasan dan intelektual manusia yang berupa hak cipta, paten, dan hak atas merek, desain

\footnotetext{
${ }^{16}$ Pasal 22 UU No. 37 Tahun 2004

${ }^{17}$ Pasal 499 BW

${ }^{18}$ Rachmadi Usman, Hukum Hak atas Kekayaan Intelektual: Perlindungan dan Dimensi Hukumnya di indonesia, 2003, h. 39.

19 Pasal 504 BW.

${ }^{20}$ R. Subekti, Hukum Pembuktian, Pradnya Paramita, Jakarta, 2001, h. 61-62.
}

industri, rahasia dagang, dan desain tata letak sirkuit terpadu. ${ }^{21}$

Hak kebendaan masuk ke dalam bilangan hak atas harta kekayaan. Hak atas harta kekayaan adalah hak yang dapat dibilai dengan uang. Karakteristik hak atas harta kekayaan adalah hak yang dapat dialihkan.

Hak kebendaan memberikan kepada pemegangnya kekuasaan atas benda yang dikuasainya. Hak itu dapat berupa penggunaan atau penikmatan suatu benda atau kadang-kadang hanya merupakan tolok ukur atas suatu nilai ekonomis untuk suatu kepastian. ${ }^{22}$

Hak Atas Kekayaan Intelektual merupakan bagian dari hak kekayaan atau hak kepemilikan yang memiliki niai ekonomi karena adanya hak eksklusif untuk mengeksploitasi tersebut. Hak milik merupakan hak ekslusif untuk menguasai, menikmati, dan mengatur suatu objek atau hak-hak yang memiliki nilai ekonomi, Hak atas Kekayaan intelektual memberikan keuntungan ekonomis bagi pemegang hak. ${ }^{23}$

Hak Atas Kekayaan Intelektual merupakan hak yang berasal dari hasil kegiatan kreatif suatu kemampuan daya pikir manusia yang diekspresikan kepada khalayak umum dalam berbagai bentuknya, yang memiliki manfaat serta berguna dalam menunjang kehidupan manusia juga memiliki nilai ekonomis.

Hak ekonomi merupakan hak untuk mendapatkan manfaat ekonomi atas ciptaan serta produk hak terkait. Secara umum, hak ekonomis merupakan hak eksklusif dari pengarang untuk memperoleh keuntungan ekonomi. Hak ekonomis ini meliputi hak memperbanyak, hak distribusi, hak pertunjukan dan hak peragaan. ${ }^{24}$

Hak atas Kekayaan Intelektual termasuk di dalam pengertian harta kekayaan debitor sebagaimana yang dicantumkan di dalam Pasal 21 UU No. 37 Tahun 2007, sehingga Hak atas Kekayaan juga masuk di dalam harta pailit sebagaimana harta kekayaan

21 Peter Mahmud Marzuki, Pengantar Ilmu Hukum, Prenadanamedia Group, Jakarta, 2015, h. 175.

22 Ibid, h. 174.

${ }^{23}$ Djuhaendah Hasan, Lembaga Jaminan Kebendaan bagi Tanah dan Benda Lain yang Melekat Pada Tanah dalam Konsepsi Penerapan atas Pemisahan Horizontal pada Tanah Dalam Konsepsi Penerapan atas Pemisahan Horizontal (Suatu konsep dalam Menyongsong Lahirnya Lembaga Hak Tanggungan), Citra Aditya Bakti, Bandung, h. 43.

${ }^{24}$ Abdul R Saliman dkk., Hukum Bisnis untuk Perusahaan, Kencana, Jakarta, 2005. 
lainnya, sehingga yang memiliki kewenangan dalam hal ini bukan lagi debitur akan tetapi kurator sebagai wali atas debitur.

\section{Akibat Kepailitan terhadap Seluruh Perbuatan Hukum Debitur yang Dilakukan Sebelum Putusan Persyaratan Pailit Diucapkan}

Segala perbuatan hukum debitur yang dinyatan pailit, yang merugikan kepentingan kreditor, yang dilakukan sebelum putusan pernyataan pailit diucapkan, dapat dimintai pembatalan oleh kreditor kepada pengadilan. Sistem pembuktian yang dipakai adalah sistem pembuktian terbalik, artinya beban pembuktian terhadap pembuatan hukum debitur, tersebut berada pada pundak debitur pailit dan pada pihak ketiga yang melakukan perbuatan hukum dengan debitur apabila perbuatan hukum debitur tersebut dilakukan dalam jangka waktu 1 tahun merugikan kepentingan kreditor, maka debitur dan pihak ketiga wajib membuktikan bahwa perbuatan hukum tersebut wajib dilakukan oleh mereka dan perbuatan hukum tersebut tidak merugikan harta pailit. Apabila lebih dari satu tahun, maka yang wajib membuktikan adalah kurator. ${ }^{25}$

Perjanjian timbal balik yang belum atau baru sebagian dipenuhi, pihak yang mengadakan perjanjian dengan debitur dapat meminta kepada kurator untuk memberikan kepastian tentang kelanjutan pelaksanaan perjanjian tersebut dalam jangka waktu yang disepakati oleh kurator dan pihak tersebut. ${ }^{26}$

Dalam apabila dalam jangka waktu tersebut kurator tidak memberikan jawaban mengenai jangka waktu, maka hakim pengawas akan memberikan jangka watu, dan apabila kurator tidak bersedia untuk memberikan jawaban atau pelaksanaan perjanjian tersebut, maka pihak dalam perjanjian tersebut dapat menuntut ganti kerugian dan diberlakukan sebagai kreditur konkuren. Apabila kurator menyanggupi, maka kurator harus memberikan jaminan atas kesanggupan untuk melaksanakan perjanjian tersebut.

\section{Perjanjian Franchise sebagai Perjanjian Timbal Balik yang Dilakukan oleh Debitur ketika Terjadi Kepailitan}

Perjanjian franchise pada dasarnya merupakan suatu perjanjian timbal balik yang dilakukan oleh franchisee dan franchisor, sehingga masing-masing

\footnotetext{
${ }^{25}$ Pasal 41 dan Pasal 42 UU No. 37 Tahun 2004

${ }^{26}$ Pasal 36 UU No. 37 Tahun 2004.
}

pihak sama-sama memiliki hak dan kewajiban satu sama lain. Apabila franchisor mengalami kepailitan, maka segala kekayaannya akan masuk ke dalam budel pailit dan perjanjian yang dilakukan akan masuk di dalam perjanjian di dalam Pasal 36 dan Pasal 37 UU No. 37 Tahun 2004. Oleh sebab itu, maka ada dua upaya yang dapat dilakukan oleh franchisee: meminta kepastian kepada kurator mengenai kelanjutan perjanjian franchise tersebut; meminta ganti kerugian dengan cara bertindak sebagai kreditor konkuren.

Apabila tidak ada kepastian dari kurator, maka franchisee dapat mengajukan permohonan kepada hakim pengawas untuk memaksa agar kurator segera memberikan kepastian dari kelanjutan perjanjian franchise.

Penting kiranya franchisee mengajukan permohonan kepada kurator guna meminta kepastian kelanjutan dari perjanjian franchise, sebab perjanjian franchise memiliki perbedaan yang sangat besar dengan perjanjian timbal balik yang lainnya. Sebab perjanjian ini terkait dengan usaha dari franchisee, apakah dapat dijalankan atau tidak. Meskipun nantinya franchisee dapat meminta ganti kerugian dan dimasukkan ke dalam kreditor, akan tetapi belum tentu nantinya franchisee akan mendapatkan ganti kerugian seperti yang diharapkan. Hal tersebut mengingat dalam hal ini franchisee hanya akan berposisi sebagai kreditor konkuren saja, yaitu sebagai kreditor yang hak tagihnya paling terakhir di antara para kreditor lainnya di bawah kreditor separatis dan kreditor konkuren.

Perlindungan hukum kepada franchise akan lebih ditingkatkan lagi apabila di dalam perjanjian franchise juga dimuat klausula mengenai kelanjutan dari perjanjian manakala terjadi franchisor mengalami kepailitan, sehingga dapat hal ini franchisee tidak akan dirugikan.

\section{PENUTUP}

Hak Kekayaan atas Intelektual dapat dikatakan merupakan barang yang dimasukkan ke dalam sita umum ketika terjadi kepailitan sebab merupakan benda yang dapat dijadikan jaminan menurut BW;

Perlindungan hukum dibagi menjadi dua perlindungan hukum represif dan perlindungan preventif. Perlindungan hukum preventif, dapat dilakukan dengan cara memuat sebuah klausula mengenai kelanjutan perjanjian franchise apabila franchisor mengalami pailit; 
Perlindungan hukum represif dapat dilakukan dengan dua cara, perjanjian franchise merupakan perjanjian timbal balik sehingga terdapat dua alternatif penyelesaian; yang pertama adalah meminta kepastian kelanjutan perjanjian kepada kurator sebagai wali dari franchisor atau meminta ganti kerugian sebagai kreditor konkuren.

\section{Rekomendasi}

Pengaturan mengenai kelanjutan perjanjian franchise apabila franchisor mengalami kepailitan harus segera dilakukan, mengingat kepailitan dapat saja merugikan franchisee, apabila nantinya kurator memilih untuk tidak meneruskan perjanjian franchise;

Perlunya pemberian penyuluhan agar para pihak yang melakukan perjanjian franchise mencantumkan klausula mengenai kelanjutan perjanjian franchise apabila terjadi kepailitan franchisor;

Apabila tidak merugikan harta debitor, dalam hal ini franchisor, lebih baik apabila kurator meneruskan perjanjian franchise, mengingat hal tersebut menyangkut kelangsungan usaha dari franchisee.

\section{DAFTAR PUSTAKA}

\section{Peraturan Perundang-undangan:}

Burgerlijk Wetboek.

Undang-Undang Nomor 37 Tahun 2004 tentang

Kepailitan dan dan Penundaan Kewajiban Pembayaran.

PP Nomor 42 Tahun 2007 tentang Waralaba.

Peraturan Menteri Perdagangan Republik Indonesia Nomor 53/M-DAG/PER/8/2012 tentang Penyelenggaraan Waralaba.

\section{Buku:}

H.S, Salim, 2010, Perkembangan Hukum Kontrak Innominaat di Indonesia, Jakarta: Sinar Grafika. , 2005, Perkembangan Hukum Kontrak di Indonesia, Jakarta: Sinar Grafika.
Hasan, Djuhaendah, Lembaga Jaminan Kebendaan bagi Tanah dan Benda Lain yang Melekat pada Tanah dalam Konsepsi Penerapan atas Pemisahan Horizontal pada Tanah dalam Konsepsi Penerapan atas Pemisahan Horizontal (Suatu Konsep dalam Menyongsong Lahirnya Lembaga Hak Tanggungan), Bandung: Citra Aditya Bakti.

Margono, Suyud, 2010, Aspek Hukum Komersialisasi Aset Intelektual, Bandung: Nuansa Aulia.

Marzuki, Peter Mahmud, 2015, Pengantar Ilmu Hukum, Jakarta: Prenadanamedia Group.

Mendelson, Martin, 1997, Franchising, Petunjuk Praktis Bagi Martin Mendelson, Franchising, Petunjuk Praktis Bagi Franchisor dan Franchisee, Jakarta: Pustaka Binaman Pressindo.

Saliman, Abdul R. dkk., 2005, Hukum Bisnis untuk Perusahaan, Jakarta: Kencana.

Subekti, R., 2001, Hukum Pembuktian, Jakarta: Pradnya Paramita.

Shubhan, Hadi, Hukum Kepailitan, Prinsip, Norma dan Praktik di Peradilan, Kencana Prenadamedia Group, Jakarta.

Sumarsono, Sonny, 2009, Manajemen Bisnis Waralaba, Yogyakarta: Graha Ilmu.

Usman, Rachmadi, 2003, Hukum Hak atas Kekayaan Intelektual: Perlindungan dan Dimensi Hukumnya di Indonesia.

\section{Internet:}

CSBisnisUKM, Bagaimana Cara Menghadapi Persaingan Pasar?,http://bisnisukam.com/ Bagaimana-Cara-Menghadapi-Persaingan-Pasar. html, diakses pada tanggal 4 Oktober 2015.

Administrator, Bisnis Waralaba Diproyeksikan naik 15-20\% Tahun ini, http://bisniskeuangankompas. co/read/ diakses pada tanggal 10 September 2014. 